\title{
МАЛАЈСКИ ПАНТУН У ФРАНЦУСКОМ РУХУ
}

Иако је малајски пантун, или пантум, устаљени песнички облик, настао на подручју Малезије и Индонезије, дакле на простору који је географски и културолошки веома удаљен од европског и америчког тла, то није представљало препреку да пронађе свој пут и у књижевностима других континената. У овом чланку говоримо о особеностима изворног пантуна, потом о његовом продору у европску књижевну традицију и посебно о распрострањености у француској књижевности, као и у северноамеричкој књижевности француског говорног израза. Истраживање показује да je у француском књижевном кругу ова специфична лирска форма прихваћена, али уз извесна прилагођавања романском културно-језичком наслеђу, док је у савременој канадској поезији на француском језику могуће пронаћи и примере који се враћају суштини изворног, малајског облика.

Кључне речи: устаљени песнички облици, малајски пантун (пантум), француска поезија, франко-канадска поезија.

1. КА ДЕФИНИЦИЈИ МАЛАЈСКОГ ПАНТУНА. У народној књИжевности распрострањеној на територији данашње Малезије и Индонезије настала је песма устаљене форме под називом $\bar{u} а н \bar{u} y н$. У поднебљу одакле потиче,

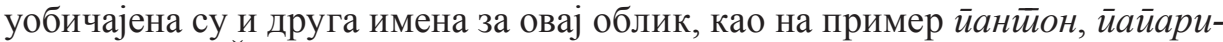
кан, йарекан (ŽIVKOVIĆ 1992: 563)1․ У њему се третирају најразличитије теме, од верских и поучних до шаљиво-сатиричних и љубавних. Ове последње су најзаступљеније.

У малајској културној традицији пантун је присутан од давнина. Настао је у усменој форми, коју никада није напустио. Рецитовао се или певао током церемонија и свечаности, али и приликом неких важних тренутака

${ }^{1}$ Према Ейнолощком извещū стотину тридесет и седам језика, те не чуди што постоје различити називи за исти појам $<$ www.wikiwand.com/sr/Малезија $>$. 
у свакодневном животу. Постоје пантуни којима се изјављује љубав, наговештавају одласци, исказују разне догодовштине, шале, покуде или мудрости. Када је ушао у писану књижевност, пантун се могао наћи у прозним текстовима, као поетски одломак, у виду монолога или дијалога (VoISSET 1997: 7).

Први писани примери пантуна датирају из шеснаестог века. Забележени су арапским писмом у тексту под насловом Династиија сулйана̂ (Sulalatus Salatin), познатијем као Малајски роgослов (Sejarah Melayu) ${ }^{2}$, за који се сматра да је настајао у периоду од 1401-1511, да би коначно био обједињен и преписан 1536. године (Ревуне́нковА 2008). Због тога се уз појам пантуна, који је нашао место у овом важном историјском спису ${ }^{3}$ уврежио епитет малајски.

Малајски пантун је лирски облик особен пре свега по својој структури, која се заснива на понављањима и бројним паралелизмима, односно на извесној симетрији, која је у писаном облику још израженија, јер се усменом (аудитивном и вокалном) аспекту придружује и визуелни. Паралелизам се уочава најпре у броју стихова, којих има четири (дакле, реч је о катрену), а сваки стих сачињен је од по четири речи. Свака реч има два, највише три слога, тако да је број слогова у стиху најмање осам, што је најчешћи случај, или пак већи, али не прелази дванаест. Изабрани број слогова у првом стиху задржава се до краја песме, чиме се постиже устаљени ритам.

Паралелизам се огледа и у фонетској структури. Пантун је милозвучна лирска песма која обилује римама. Њена гласовна организација из прва два стиха пресликава се у наредна два. Уобичајено је присуство укрштене риме, абаб, али су честе и унутрашње, које могу да иду дотле да се све речи римованих стихова такође римују (VOISSET 1997: 7-8).

И семантички ниво песме подразумева одређени паралелизам. Тачниje, реч је о бипартитној структури у којој се тема, песничка слика, или ређе поента, изнета у првој половини катрена, налази и у наставку, односно у наредна два стиха, али у нешто измењеном облику. ${ }^{4}$ Другим речима, тематски

2 Преводи на европске језике датирају из деветнаестог века. Први од њих био је превод на енглески језик, шкотског оријенталисте Џона Лејдена (John Leyden), који није доживео његово штампање. Наиме, објављен је 1821. године у Лондону, десет година након преводиочеве смрти. У дигитализованом облику овај превод је доступан и на интернету.

3 Пантуни се налазе на стр. 83, 316. и 330.

4 Жак Жуе (Jacques Jouet), члан групе Улипо (Oulipo) - радионице за потенцијалну књижевност (фр. Ouvroir de Littérature Potentielle), коју су основали француски књижевници и математичари 1960. године ради експериментисања са применом математичких модела на књижевно стваралаштво - описује пантун као структуру понављања која има облик катрена у којем је први двостих денотативан, дескриптивног карактера, посвећен опису неког догађаја из свакодневице или из историје, док су наредна два стиха интимистичка и представљају носиоце емоционалног стања. У њима песник износи свој субјективни доживљај, као допуну претходном двостиху (JoUEт 2005: 20-21). Иако у личном тону, други двостих може имати вредност опште истине или износити морални суд и тада исказ наликује пословици или наравоученију из басне у стиху (CHISHOLM 1911: 686). Иако се може чинити да су у супротности, први и други део катрена су, заправо, комплементарни. 
наговештај из прве половине песме развија се у наставку, односно надаље не може бити изневерен, јер нема увођења нових тема. Често су присутне игре речима, сваковрсна понављања морфема, слика или симбола, с намером да се обезбеди јединство у идејном смислу, као и јединство тона. Ипак, има и случајева у којима таква пренапрегнутост текста у скученом језичком простору катрена проузрокује сасвим супротан ефекат, односно доприноси настанку потешкоћа у разумевању поруке. Те потешкоће настају и као последица чињенице да је пантун проистекао из усмене традиције, која допушта извесне текстуалне импровизације приликом изговарања (рецитовања или певања) стихова, које се руководе, пре свега, звучном сликом. Може се приметити да се такви случајеви, управо због краткоће форме (свега четири стиха) и могућег присуства импровизација приближавају поетици других источњачких фолклорних облика, на пример поетици руских и украјинских

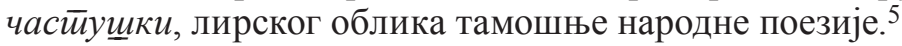

Пантун уобичајено има четири стиха, али постоје и дужи облици, који

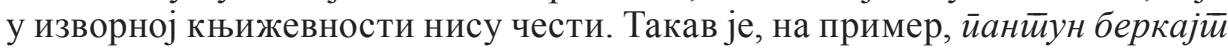
(pantun berkait), што у преводу значи уланчани йанйшн. Састављен је из више катрена, те се самим тим могућности понављања сегмената или спровођење одређених формалних паралелизама из строфе у строфу умножавају и преплићу.

Управо овакви, необично сложени облици привукли су европске песнике с почетка деветнаестог века. Но, без обзира на дужину поетског текста (било да је реч о једном или о низу катрена), европски песници су све те облике сматрали истоврсном источњачком лирском формом, називајући их истим именом, $\bar{u} а н \bar{u} y н$, или како се грешком усталио у француској транскрипцији са суфиксом -ум, йанӣум (VOISSET 1997).

2. ПродОР ПАНТУНА у ЕВРОПСКУ КњИЖЕВНУ тРАДИцИЈу. Малајска поезија веома је развијена и има дугу традицију која траје и данас. Негују се бројни

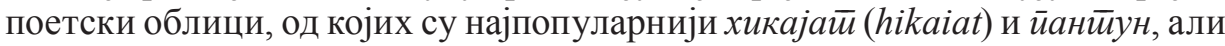
се једино овај други раширио из малајског језика и културе у друге језике и средине (www.wikiwand.com/sr/Малезија).

У европским књижевностима малајски пантун није присутан пре деветнаестог века. Једноставно, за њега се није знало. Под утицајем посве другачије књижевне традиције и укуса од изворне ${ }^{6}$, у европској поезији

5 Реч је о облику народне поезије, углавном љубавне тематике, где девојка изговара монолог од четири стиха (катрен), који је често прожет хумором. По својој структури и тону приближавају јој се украјинска каломајка и српскохрватски бећараи (видети ниже). Код руских аутора примери инспирисани овим народним обликом, али у дужој форми, могу се пронаћи у поезији Владимира Мајаковског (Влади́мир Маяко́вский) и Александра Блока (Алекса́ндр Блок) (ŽıvкоVIĆ 1992: 115).

${ }^{6}$ Европске књижевности потекле су на истим основама, из времена средњовековног латинитета, када је владало језичко и културно јединство, које је, потом, обликовало 
најчешће се налази као дужи песнички облик, који је састављен од више катрена, чак читавог низа, у којима се, према изворном правилу беркајй $а$, односно уланчаног пантуна, други и четврти стих прве строфе понављају као први и трећи стих друге строфе, при чему се такав систем спроводи доследно на читаву песму, односно други и четврти стих друге строфе истоветни су са првим и трећим стихом наредне, треће строфе, и тако редом (JoUET 2005: 16).

Постоје и циклични пантуни, који су веома чести у западноевропској поезији, али не и у изворној. У њима су иницијални и последњи стих песме идентични (JARRETY 2010: 304). Жак Жуе (Jacques Jouet) сасвим исправно закључује да се у систему понављања које важи за циклични уланчани пантун могу појавити највише две риме (2005: 17), дакако укрштене. Ову моду цикличних или затворених песама, која је, наравно, већ постојала код европских сонета, предложио је и применио на пантуне француски песник Теодор де Банвил (Théodore de Banville) у свом Малом йрактиайу о франиуској йоезији (Petit traité de poésie française) из 1872. године, где је поред устаљеног распореда рима и принципа понављања стихова увео и треће начело за писање пантуна, а то је циклична форма ${ }^{7}$ (BANVILLE 1872: 221), односно увео je „правило завршне речи“ (,,règle de clausule“), које ће постати широко усвојени модел међу француским песницима. Тако се, заправо, створио фран-

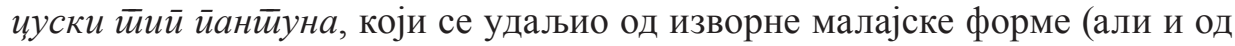
његове суштине!) и приближио укусу европског читаоца (VoISSET 1997: 13).

Будући да је реч о специфичном виду поигравања са формом, малајски пантун је морао оставити утисак на песнике епохе романтизма, који су се окретали Оријенту и свему што је изгледало егзотично и што је представљало новину. Истраживали су га и модификовали, уносећи свој лични поетски печат. Стога није могуће говорити о европском пантуну као јеgинстивеној иесничкој форми, већ само о јеgинсиивеној инсиииацији.

нововековне књижевности на народним језицима. Стога поетске појаве неког периода не можемо посматрати као механички сабране, него као појаве које чине органско јединство (Грдинић 2000: 8), у којем је могуће пратити с једне стране развој класичних поетских облика, а са друге, оне које чине модификоване или посве нове, куриозне форме, које је Ернст Роберт Курцијус (Ernst Robert Curtius) назвао маниризмима, и сматрао их константом европских књижевности, комплементарној класици, која је узета за норму. У овом смислу говорећи, продор једне ваневропске форме у европски књижевни круг представља пример који није више ни одступање од норме ни модификација уврежене традиције, него потпуно нови културолошко-стилски елемент, који излази из оквира евройских маниризама. Због велике културно-језичке разлике (видети ниже), пантун и није могао бити прихваћен без претходних прилагођавања постојећој традицији и укусу циљне културе. Иако га називамо малајским, то чинимо због његове везе са земљом настанка, али не и због верности изворном облику. Заправо, било би тачније назвати га евройским (француским, енглеским, немачким и тако редом) и тако га разликовати од изворне поетске форме из које је настао деривацијом. Јер, европски пантун се, као што ћемо видети, еманциповао.

${ }^{7}$ Ово правило већ се појављивало у сонетима, а подразумева да песма завршава истим стихом којим је и почела. Тиме се ствара утисак бескрајног кружног тока. 
2.1. ПАнтун у ЕВРОПским књижЕвностима. Распрострањеност пантуна у европским књижевностима варира, али се grosso modo може рећи да је реч о ретко заступљеној песничкој врсти, која се, понекад, мери појединачним примерима у оквиру националне књижевности.

Хронолошки посматрано, први пантуни на европском тлу, како наводи Жуе (2005), објављени су на енглеском језику, у Лондону 1812. године, у књизи оријенталисте Виљема Марздена (William Marsden) посвећеној малајском језику, под насловом Грамат̄ика малајской језика (A Grammar of the Malayan Language). У њој се налазе Марзденови препеви ${ }^{8}$. Тек много година касније настаће прво оригинално остварење на енглеском језику (које датира из 1876. године), чији аутор је Остин Добсон (Austin Dobson). До тада је у Немачкој већ објављена оригинална песничка збирка на немачком језику, инспирисана овим источњачким обликом, У малајском облику (In malayischer Form, 1821). Управо писац ове збирке, Аделберт фон Шамисо (Adelbert von Chamisso), надахнуће Јаноша Арања (János Arany), мађарског песника деветнаестог века, да сачини први и до сада једини познати пантун на мађарском језику, писан осмерачким стихом, под насловом Вийез Бор (Bor vitéz, 1855) (SZILÁGYI 2009: 271). ${ }^{9}$

Ни на другим језицима није много заступљен. Наиме, на руском језику пантуне је писао Валериј Брјусов (Вале́рий Я́ковлевич Брю́сов), Николај

${ }^{8}$ Марзден даје четири примера малајског пантуна, које је превео с арапског на енглески језик. Жуе наводи да је један од тих примера преведен 1824. године на француски језик, али без рима и слободним стихом. Француски преводилац није назначен. Реч је о следећим стиховима:

The heron into the air

And dashes down the fish it had caught.

Forbear to grasp burning embers,

Or, feeling the heat, you quickly let them go (Jouet 2005: 18).

У француској верзији стихови гласе:

Le héron plane dans l'air,

Et engloutit le poisson qu'il avait pris

Gardez-vous de ramassez des cendres ardentes,

Ou, sentant la chaleur, vous les lâcherez promptement (Jouet 2005: 20).

9 Реч је о уланчаном пантуну састављеном од четрнаест катрена. Наводимо само прва два:

Ködbe vész a nap sugára,

Vak homály ül bércen-völgyön.

Bor vitéz kap jó lovára:

„Isten hozzád, édes hölgyem!“‘

Vak homály ül bércen-völgyön,

Hüs szél zörrent puszta fákat.

„Isten hozzád, édes hölgyem!

Bor vitéz már messze vágtat“" (SZILÁGYI 2009: 271). 
Гумиљов (Никола́й Степа́нович Гумилёв), Аделина Адалис (Адели́на Ада́-

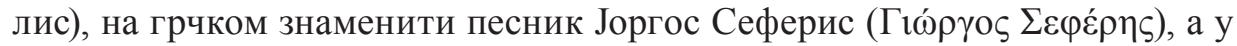
српској књижевности једино се може пронаћи у песничком опусу Владимира В. Предића (RUžIć 2008: 139). ${ }^{10}$

3. МАЛАЈСКИ ПАНТУН У ФРАНЦУСКОМ КњИЖЕВНОМ КРУГУ. У ФраНцУсКој, осим анонимног препева из 1824. године (в. подножну напомену број 8), као познавалац малајског пантуна појавиће се велики песник Виктор Иго (Victor Hugo). Наиме, нецикличну песму од четири катрена, коју је посудио из Марзденове Грамайике (VOISSET 1997: 59), Иго је дао Ернесту Фуинеу (Ernest Fouinet $)^{11}$, оријенталисти који је за њега и раније преводио одломке са арапског, персијског и других оријенталних језика, да је препева на енглески. Иго ју је потом објавио на француском под једноставним насловом Малајски $\bar{u}$ aнйин (Pantoum malais), оцењујући да је то само један у прегршту драгуља из великог рудника какав је Оријент (Hugo 1913: 562). Ти стихови ${ }^{12}$ налазе се на крају књиге, у Белешкама (Notes) у оквиру збирке Opијенйалке (Les Orientales), која је изашла из штампе 1829. године (Hugo 1913: 561-562) ${ }^{13}$. Иако се Иго није стриктно придржавао паралелизама (број слогова варира, изостале су риме, понеки поновљени стих је модификован у наредном по-

10 У српској народној поезији, пантун би се, уз извесне ограде, могао довести у везу са шаљивим бећарием и са бачванским иеесмама (ŽIvкоvić 1992: 81-82). Расправа о овој теми била би вредна пажње.

${ }^{11}$ Сарађивао је са Игоом и за њега преводио текстове и одломке с арапског, као и са других оријенталних језика.

12 Банвил наводи како је Игоов превод начињен у прози (BANVILLE 1872: 217). Ту грешку ће многи потоњи аутори преписивати, без претходне провере.

${ }^{13}$ Иго наводи ове стихове не дајући уз њих додатна појашњења:

Les papillons jouent à l'entour sur leurs ailes;

Ils volent vers la mer, près de la chaîne des rochers.

Mon cœur s'est senti malade dans ma poitrine,

Depuis mes premiers jours jusqu'à l'heure présente.

Ils volent vers la mer, près de la chaîne des rochers...

Le vautour dirige son essor vers Bandam.

Depuis mes premiers jours jusqu'à l'heure présente,

J'ai admiré bien des jeunes gens.

Le vautour dirige son essor vers Bandam...

Et laisse tomber de ses plumes à Patani.

J'ai admiré bien des jeunes gens;

Mais nul n'est à comparer à l'objet de mon choix.

Il laisse tomber de ses plumes à Patani...

Voici deux jeunes pigeons!

Aucun jeune homme ne peut se comparer à celui de mon choix,

Habile comme il l'est à toucher le cœur. (Hugo 1913: 561-562). 
јављивању), мора се приметити да је Иго први скренуо пажњу на постојање ове, како је навео, „прекрасне“ и „оригиналне“ лирске форме (,,un pantoum ${ }^{14}$ ou chant malais, d'une délicieuse originalitée", Hugo 1913: 561). Она ће се нарочито допасти француским песницима Парнаса попут Теофила Готјеа (Théophile Gautier), Теодора де Банвила, Леконта де Лила (Leconte de Lisle), и постати им извор инспирације. Може се рећи да су (тек) парнасовци удахнули живот овој врсти песме на француском језику, мењајући је према укусу епохе, те су уводили тему светске боли (фр. mal du siècle) као и неке нове захтеве који се тичу форме, попут избора стиха (углавном александринца) или пак бинарне презентације теме, инсистирајући на развијању две идеје које се правилно смењују у етапама од по два узастопна стиха.

Будући да су били опчињени савршенством форме, песници Парнаса ће у потпуности усвојити источњачки пантун и дати му на значају исто колико и другим европским устаљеним облицима (фр. formes fixes) потеклим из средњовековне и ренесансне песничке традиције (пре свега сонету, али и другим облицима као што су рондо, балада, децима и тако редом), чија поетика наликује поетици малајских уланчаних пантуна. И, уврстиће га у свој уобичајени песнички репертоар. Разлог што их је пантун привлачио лежи, свакако, у сложености захтева̂ који се постављају пред песника жељног поетских изазова, који се у овом случају састоји у томе да је потребно да се састави с једне стране формално строго уређена, а са друге стране идејно (пре свега на семантичком, али и на лексичко-синтаксичком нивоу) врло одређена а складна стихована целина. Тај изазов обогатиће француску и уопште читаву европску поезију деветнаестог века ${ }^{15}$, и наставиће да постоји и касније.

Када је реч о француској књижевној историји, поред песника̂ Парнаса ${ }^{16}$ и симболиста, и Бодлер (Baudelaire) ће писати песме базиране на понављањима.

${ }^{14}$ Како Воасе наводи, Игоова транскрипција је пофранцужена (ради очувања изговора у писању се уместо вокала - $u$ налази -ou), али се грешка у коначној транскрипцији појма приписује процесу штампања књиге, приликом којег она није уочена и отклоњена, те се на месту крајњег консонанта $-n$ нашло -m (pantoum). Појам је у том облику широко прихваћен у француској књижевности и култури. Једино су Жерар де Нервал (Gérard de Nerval) и Леконт де Лил били доследни у коришћењу исправне транскрипције (pantoun). Воасе наводи да Де Лил није дозвољавао грешку вероватно због свог реинионског порекла и близине Индијском Океану (VoISSET 1997).

15 Устаљени песнички облици, уопште узев, интригантни су за ствараоце, јер је потребно изборити се са законитостима сваког појединачног облика, ма колико био комплексан. Како Сања Париповић Крчмар примећује за песнике српског неосимболизма који су волели да користе сталне песничке облике, за њих је „постизање модела које облик тражи [...] представљао изазов, док је с друге стране [то] била својеврсна потврда њиховог талента“ (ПАРиПовић Крчмар 2017: 127). Додајмо да што је облик захтевнији, изазов је већи. Ово је, свакако, универзална одлика која важи за песнике свих епоха и свих меридијана.

${ }^{16}$ Међу ауторима који се инспиришу пантуном Банвил наводи Шарла Аселиноа (Charles Asselineau) и Лујзу Сифер (Louisa Siefert). Од познатих песника поменимо још Албера Глатињија (Albert Glatigny) и Ренеа Гила (René Ghil). 
Иако и он одступа од строгих захтева изворног пантуна, као што уосталом чине сви француски песници ${ }^{17}$ (JARRETY 2010: 304), његове песме одражаваjу поетику овог малајско-индонежанског облика и постављају Бодлера на чело француских стваралаца који се њиме надахњују (в. ниже).

3.1. ПАНТУН У ФРАНКОФОНОЈ КАНАДИ. Овај ПеСНИЧКИ обЛИК доспео је и На северноамерички континент. Како је франко-канадска књижевност верно пратила догађања на француском књижевном небу, тако је током деветнаестог века прихватила тамошњи романтичарски укус и идеје, као и моду писања устаљених песничких форми. Поред Ламартина (Lamartine), Мисеа (Musset) и Вињија (Vigny), Иго је представљао највећу инспирацију читавој једној генерацији писаца, а од устаљених песничких врста, сонет је постао најдоминантнија форма. Међутим, песничко умеће одмеравало се и коришћењем других устаљених облика, те је и пантун у другој половини деветнаестог века добио своје место, али само као инспирација, код песника као што су Франсоа Гзавије Гарно (François-Xavier Garneau), Франсоа Маглоар Дером (François-Magloire Derome) (в. Des poètes méconnus du Québec 2002), који нису остварили велике домете у поезији, и код песника Монтреалске школе, која се развијала од самог краја века све до половине четврте деценије наредног века када се угасила (1895-1935). Припадници ове чувене школе, на челу са истакнутим песником Емилом Нелиганом (Émile Nelligan), по многима најзначајнијим песником тог периода, имали су своје узоре међу француским и белгијским ауторима, пре свега међу парнасовцима, који су волели да експериментишу са песничком формом. Тако су и у канадској књижевности модификације постале уобичајени модел писања, те се примери поетских остварења која почивају на паралелизмима, у ствари, тешко могу сврстати у праве пантуне. На пример, узори за чувену песму Рийам ноћи (Rythmes du soir) Емила Нелигана били су Бодлерова Хармонија вечера (Harmonie du soir) и Верленова (Verlaine) Месечина (Clair de lune), песме које су се већ удаљиле од пантуна, те не чуди што Нелиганови стихови имају још мање заједничког са малајским обликом, за који он, очигледно, није много марио.

Заправо, први пример малајског пантуна у канадској књижевности француског говорног израза, потпуно изненађујуће, датира из времена пре

17 Ако се сложимо са тврдњом Пјера Гироа (Pierre Guiraud) да је за версификацију важно да ли је она силабичка попут француске, акценатска попут германске, или пак квантитативна, попут грчко-латинске (GUIRAUD 1978: 9-11), увидећемо да је понекад немогуће доследно пренети устаљену песничку форму у њеном посве изворном облику. Осим тога, постоје и бројна морфолошка, граматичка и лексичко-семантичка ограничења, што један идиом који, примера ради, има члан, као што га има француски језик, чини потпуно непријемчивим за увођење кратке форме од свега једног катрена у којем би стихови имали по четири речи. Овај (немогући) изазов поједини француски песници су прихватили, али уз примену, можемо слободно рећи неизбежних, песничких слобода. Уз ову тврдњу додајмо да је и превођење пантуна изузетно захтеван подухват, нарочито уколико постоје разлике у природи полазног и циљног језика и/или типу версификације о којој говори Гиро. 
романтичарских уплива на северноамерички континент (пре Игоовог „промовисања“"пантуна, али, немојмо сметнути с ума, после енглеског превода Малајскоі родослова!), у песничком опусу изразито плодне песникиње Лидије Сежурне (Lydia Séjourné). Пантун се потом јавља у знатно каснијем периоду од романтичарског.

Наиме, новинарка и песникиња Лидија Сежурне, била је позната и призната у свом родном Напијервилу, где се активно бавила писањем током прве половине и средином деветнаестог века. Тематски опсег који је често присутан у њеном списатељском опусу није необичан за новинара, али за поетско стваралаштво свакако јесте. Реч је о економским и трговачким темама. Она је за собом оставила више од две хиљаде чланака и четрдесет и шест збирки текстова. Године 1815. објавила је збирку под насловом Oge o $\bar{u} p \bar{\imath} o-$ вини (Odes aux échanges), у којима се налазе стихови о склапању и о раскидању уговора, о набавци робе и сличним пословима везаним за економску струку (в. http://www.udenap.org/groupe_de_pages_06/poesie_feminine_napierville.htm). У том духу настао је и њен једини пантун, у којем је реч о развоју рингита у Малезији. Песма носи наслов Ринїий је малајска валуйа (Le ringgit est l'unité monétaire de la Malaisie) (SzILÁGYI 2009: 272).

Готово читав век касније, тачније 1913. године, једна друга песникиња по имену Бланша Ламонтањ (Blanche Lamontagne), објавиће изузетно значајну збирку посвећену животу на северноамеричком полуострву Гаспе, коју је назвала Гасйезијанске визије (Visions gaspésiennes). У њој се налази пантун под насловом Зوраво малени (Salut petit gas) ${ }^{18}$. Ова песма се у савременој канадској критици још увек сматра првим примером пантуна у канадској књижевности француског говорног израза (SAINT-JACQUES 2005: 344), вероватно јер је објављена у песничкој збирци која је награђена управо због (тада се чинило) „првог коришћења“ захтевне малајске форме, као и због присуства патриотских тема. ${ }^{19}$

Пантун је надаље тешко пронаћи у франко-канадској књижевности. У другој половини двадесетог века, у поезији Жералда Годена (Gérald Godin) налази се песма шаљивог карактера под насловом Назови-йанйун (Quasipantoum espérant), која је објављена 1960. године у збирци Бащ наивне иесмме

18 То је уланчани пантун цикличне форме. Прве две строфе гласе:

Salut, petit gas de campagne,

Chers petits hommes de chez nous!

La paix du ciel vous accompagne,

Nous vous regardons à genoux...

Chers petits hommes de chez nous,

Vos grands yeux bleus sont pleins de flamme.

Nous vous regardons à genoux,

Vous avez tout l'azur dans l'âme! (LAMONTAGNE 1913: 22).

${ }^{19}$ Реч је о награди коју јој је доделило Друштво за очување француског језика у Канади (Société du Parler Français au Canada), основано 1902. године. 
(Chansons très naïves). Може се уочити како и сам наслов алудира на присуство извесне дозе неозбиљности, а заправо реч је о немарном односу према паралелизмима, који су, као што смо видели, формална одлика пантуна. ${ }^{20}$

У канадској књижевности писаној на француском језику поетска форма пантуна много је више присутна у двадесет и првом веку. Поменимо само Анжелу Ликс (Angèle Lux), која сву своју креативност и ерудицију усмерава у правцу истинског присвајања источњачких поетских облика, пре свега хаикуа, али и других, међу којима је свакако и $\bar{u} а н \bar{u} y н$ (в. ниже) и њиховог уобличавања у њен матерњи језик, француски.

3.2. КАРАКТЕР ФРАНЦУСКИХ ПАНТУНА. Да бисмо заКљУЧИЛИ Какав је, заправо, француски облик малајског пантуна, довољно је да погледамо најчешће цитиране песме. Потребно је нагласити да чувена Бодлерова песма Хармонија вечера из збирке Цвеће зла (Les Fleurs du mal, 1857) ${ }^{21}$ представља

20 Четири катрена са укрштеним римама које прелазе у парне у трећој строфи, као и несталним метром (у распону од седам до дванаест слогова) и произвољним понављањима стихова, заиста су далеко од стриктних захтева пантуна.

21 Доносимо стихове у цлини, у оригиналу:

Voici venir les temps où vibrant sur sa tige

Chaque fleur s'évapore ainsi qu'un encensoir;

Les sons et les parfums tournent dans l'air du sir;

Valse mélancolique et langoureux vertige!

Chaque fleur s'évapore ainsi qu'un encensoir;

Le violon frémit comme un cœur qu'on afflige;

Valse mélancolique et langoureux vertige!

Le ciel est triste et beau comme un grand reposoir.

Le violon frémit comme un cœur qu'on afflige,

Un cœur tendre, qui hait le néant vaste et noir!

Le ciel est triste et beau comme un grand reposoir;

Le soleil s'est noyé dans son sang qui se fige.

Un cœur tendre, qui hait le néant vaste et noir,

Du passé lumineux recueille tout vestige!

Le soleil s'est noyé dans son sang qui se fige...

Ton souvenir en moi luit comme un ostensoir! (COLLOGNAT-BARÈs 2011: 140-141).

Такође додајемо и врло успели препев на српски језик, који је сачинио Борислав Радовић:

Ево су доба кад са дршке која се љушка

сваки цвет испарава густим обиљем ка̂да;

звуци и мириси круже вечером што пада;

вртоглавица страсна док сетни плес се слуша!

Сваки цвет испарава густим обиљем ка̂да;

Виолина дрхти као напаћена душа;

вртоглавица страсна док сетни плес се слуша!

Небо је ширно одмориште туге и склада. 
најпознатији и најцитиранији пример малајског пантуна на француском језику (COLlognat-BARĖs 2011: 140-141), иако се врстом стиха и структуром понављања аутор удаљава од захтева̂ изворног источњачког облика, истовремено се приближавајући поетици formes fixes - класичних европских устаљених песничких форми.

Мишела Акијен (Michèle Aquien) са Универзитета Париз XII сматра да је осмерачка Тужбалица о йокојници (Complainte de la bonne défunte ${ }^{22}$ ) Жила Лафорга (Jules Laforgue), коју је објавио у збирци Тужаљке (Les Complaintes) 1885. године, такође пантун (AQUIEN 1990: 89; JARRETY 2010: 304), иако је и овде присутно видно одступање од очекиваног распореда понављања, и то чак у већој мери него што је то чинио Бодлер у својој Хармонији. Може се уочити да по спољашњем облику песма заиста наликује малајском пантуну, јер је испевана у осмерцима, чиме се постиже уобичајени ритам изворног модела пантуна. Међутим, риме нису укрштене, нити су понављања стихова уређена према правилима источњачке форме. Ипак, у идејном смислу,

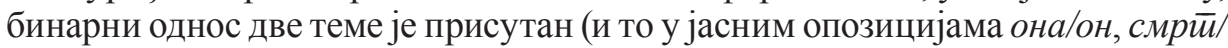

Виолина дрхти као напаћена душа,

благо срце, што би да црну празнину слада!

Небо је ширно одмориште туге и склада;

утопило се сунце у крв што му се груша.

Благо срце, што би да црну празнину свлада,

Упија сјај прошлости који се још пенуша!

Утопило се сунце у крв што му се груша!

Спомен твој као путир у мени блиста сада! (БодлЕР 1982: 65).

22 Стихови гласе:

Elle fuyait par l'avenue,

Je la suivais illuminé,

Ses yeux disait: ,J'ai deviné

Hélas! Que tu m’as reconnue!“

Je la suivis illuminé!

Yeux désolés, bouche ingénue,

Pourquoi l'avais-je reconnue,

Elle, loyal rêve mort-né?

Yeux trop mûrs, mais bouche ingénue;

Eillet blanc, d'azur trop veiné;

Oh! oui, rien qu'un rêve mort-né,

Car, défunte elle est devenue.

Gis, œillet, d'azur trop veiné,

La vie humaine continue

Sans toi, défunte devenue.

- Oh! je rentrerai sans dîner!

Vrai, je ne l'ai jamais connue. 


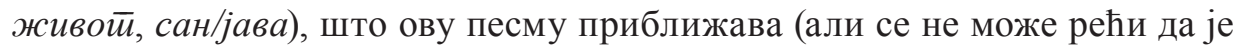
изједначава!) са уланчаним малајским пантуном. Но, утицај је и те како присутан.

Како су ово најчешће цитирани француски пантуни, намеће се закључак да француски пантуни, уопште узев, нису у потпуности верни источњачком моделу. Ако поседују неко заједничко правило, онда је то управо одсуство правила̂.

За разлику од књижевне традиције у Француској, у Канади постоје познаваоци малајског пантуна и других источњачких облика, међу којима се истиче Анжела Ликс, ауторка која је у свом стваралаштву показала не само ерудицију, него и праву песничку вештину. Иако је појављивање пантуна у франко-канадској књижевности знатно каснијег датума у односу на појаву у Француској, они су се отргли од утицаја европских маниризама (в. ниже).

4. (НЕ)СВЕСНО (НЕ)УДАљАВАњЕ ОД ИЗВОРНЕ ФОРМЕ. ПанТуни у француској књижевности нису произвели пометњу, нити су се наметнули, већ су се, напротив, умешали, готово стопили са устаљеним формама романске песничке традиције. С правом се можемо запитати да ли је романтичарски песник уопште био довољно информисан о пантуну, да ли је био свестан да се удаљава од његове строге норме, другим речима да ли је знао да ствара облик који крши начела изворног облика. Налазимо да је било таквих песника.

Теофил Готје, на пример, једну своју песму насловио је Леййири (Пан$\bar{u}$ ун) (Les papillons (Pantoum)) и уврстио је у збирку Kомеgија смрйи (La comédie de la mort), коју је објавио 1838. године, али је ту одредницу о врсти песме касније изостављао, па ће и у Сабрана geла (Les æuvres complètes) песма ући под скраћеним насловом, Леййири. Дакле, може се рећи да је свест о томе да песма није подражавала облик пантуна постојала, и учинила да ранија грешка касније буде исправљена.

Пол Верлен је, такође, имао довољно сазнања о овом малајском облику те је свој пантун, за који је сматрао да је ипак недовољно веран оригиналном облику, назвао „немарним“ (Pantoum négligé) ${ }^{23}$. Тиме је показао да је изражавање стваралачке слободе претпоставио формалним начелима. Стихове

23 Пантун гласи:

Trois petits pâtés, ma chemise brûle.

Monsieur le Curé n'aime pas les os.

Ma cousine est blonde, elle a nom Ursule,

Que n'émigrons-nous vers les Palaiseaux!

Ma cousine est blonde, elle a nom Ursule, On dirait d'un cher glaïeul sur les eaux.

Vivent le muguet et la campanule!

Dodo, l'enfant do, chantez, doux fuseaux. 
је објавио најпре у збирци Зутиччки албум (Album zutique, 1871), а касније их је уврстио и у чувену збирку Некаgа и неgавно (Jadis et Naguère, 1884). Moжемо рећи да овде никако није реч о песниковом непознавању норме, о случајности или о немарности, већ напротив, о свести да захтевни поетски облик није пренет у потпуности.

За разлику од француских песника, који јесу упознати са малајским пантуном, али га у свом језику моделирају, у канадској франкофоној књижевности има примера који успевају да остану посве верни источњачком моделу. Наиме, већ смо поменули савремену песникињу Анжелу Ликс, која се необично успешно изражава у ограничењима хаику поезије коју пише на француском језику, изврстан је познавалац и малајско-индонежанске поетске традиције. Пантун из 2002. године, који је насловила „Ипак сам

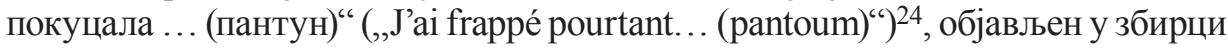
Замах крила (Courant d'ailes), у потпуности следи правила изворног облика. То је редак пример и права је срећа што су стихови ушли у чувену Анйолойију крайке йесме (L’Anthologie du poème bref, 2005).

Наиме, њена песма има цикличну, затворену форму, што је одраз француског модела пантуна, али је испевана у десетерцу, чиме се приближава

Que n'émigrons-nous vers les Palaiseaux!

Trois petits pâtés, un point et virgule;

On dirait d'un cher glaïeul sur les eaux.

Vivent le muguet et la campanule!

Trois petits pâtés, un point et virgule;

Dodo, l'enfant do, chantez, doux fuseaux.

La libellule erre emmi les roseaux.

Monsieur le Curé, ma chemise brûle! (VerLaINE 2008: 75).

${ }^{24}$ Стихови гласе:

J'ai frappé pourtant à la lourde porte

Tu ne m'as même pas prié d'entrer

Solitaire, mon âme flâne, morte,

Nostalgie en un mirage avorté

Tu ne m'as même pas prié d'entrer

Sur le seuil, je succombe à la froidure

Nostalgie en un mirage avorté

Mes lunes ennuagent mon murmure

Sur le seuil, je succombe à la froidure

Sous le bleu émail des astres crevés

Mes lunes ennuagent mon murmure

Génocide et rêves expropriés

Sous le bleu émail des astres crevés

Ma solitude me grave à l'eau-forte

Génocide et rêves expropriés

J'ai frappé pourtant à la lourde porte... (CAGLIARI et al. 2005: 97). 
малајским коренима. Понављања стихова и распоред рима (абаб) уређени су по изворним правилима. Али оно што је још важније од саме структуре

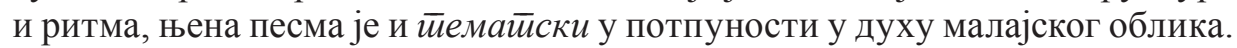
То је, заправо, најважнија особеност малајске форме, а Ликсова је успела да је изрази. За разлику од француских песника који су ту одлику одувек остављали по страни и тиме јој умањивали важност, франко-канадска песникиња управо чини супротно и истиче је као суштинску карактеристику малајске форме. Акценат је, дакле, на идејним и семантичко-лексичким паралелизмима, који се додатно обогаћују звучном сликом и тиме добијају на оној пуноћи коју имплицира изворни малајски облик. Али, осим Анжеле Ликс, нисмо уочили друге песнике који су у таквом подухвату успели.

4.1. УДАљАВАњЕ ОД СТИХОВАНЕ ФОРМЕ: ПАНТУН У ПРОЗИ. ФраНцУСКИ ПесНИК двадесетог века Ален Шеврије (Alain Chevrier), свестан постојања врло одређених захтева за писање пантуна, ипак се упушта у књижевну пустоловину, даје себи слободу да се удаљи од норме и пише Мали йрозни йанйун (Petit pantoum en prose). Овај његов књижевни експеримент одише смелошћу, али се испоставља да то није било узалуд и чак можемо констатовати да је веома успешан. Наиме, значај овог кратког пантуна лежи у томе што је писац у центар пажње поставио питање, које је у ствари кључно, а то је да ли је уопште могуће (и примерено) писати пантун у прози. Текст налазимо код Жуеа и доносимо га у целини (2005: 180):

„Un pantoum en prose, je n'en ai jamais vu. Mais ça peut se faire. Et on peut faire court. Je n'en ai jamais vu, mais en voilà un. Et on peut faire court un pantoum en prose. ${ }^{25}$

Уочава се да је тематски, као и по тону, овај прозни текст у суштини у духу малајског пантуна, у којем се сукобе две супротстављене идеје (с једне стране пантун као стиховани облик, а са друге проза), које се, коначно, измирују у преплетају форме и садржаја (пантун у прози). Наиме песник, који у првој реченици саопштава да никада није видео прозни пантун, даје читаоцу на знање да управо сада ствара и пред њега износи тако чудновату, никад раније виђену творевину. Шаљиви тон и сукоб два принципа, уз понављање синтагми и уз сталност ритма (секвенце од по шест слогова одвојене су интерпункцијским знацима, зарезом или тачком), заиста следе поетику источњачког пантуна и доводе у питање сумњу да је могуће користити прозни израз. Међутим, посебна вредност произлази из саме теме, која је учинила да овај ингениозни пантун постане, и остане, јединствен и непоновљив у историји књижевности.

25 „Пантун у прози, никада нисам видео такав. Али могуће га је начинити. И може вам се свидети. Никада нисам видео такав, али ево једног. И може вам се свидети пантун у прози“ (Превела Д. П.). 
5. ЗАКључАк. Из овог кратког осврта на основне карактеристике малајског пантуна и његових деривата, пре свега оних који су настали на франкофоном подручју, из прегледа које није имало намеру да постане коначно и свеобухватно, већ довољно да се појми какав је живот пантуна изван постојбине, може се закључити следеће: да се у пантунима на француском језику бинарност у тематском приказу и устаљеност песничког облика само донекле укрштају.

Наиме, француски песници махом иду за звучном сликом и механичким понављањима, а мање за контрастом две теме. Примери показују да су франкофони песници само препознали нови облик, који су усвајали уз извесне слободе и на различите начине. Заправо, права суштина малајског облика на другим континентима, а то значи и на другим језицима, у овом случају на француском језику у Француској и у Канади, постаје и остаје замагљена, јер се утопила у европску књижевну традицију, укорењену на латинитету и на маниризмима. Међутим, та чињеница не доприноси умањењу лирског доживљаја пантуна насталих у маниру француских романтичара, парнасоваца или потоњих генерација, него их културолошки раздваја бојећи их другачијим нијансама. Док је изворни пантун сажет и у тоновима које се чују у својеврсном стакату који прати дијалектику изнете мисли, његов француски потомак, дужи је и оставља утисак да је, како каже Boace, „моно-тон“ (,mono-tone“), односно да има само један тонални склоп, или један слој, који не доноси сву фонетско-структурну и лексичко-семантичку пуноћу изворног малајског облика.

И тако, модификујући првобитну форму, али и њен карактер, у неку новообликовану поетску целину, „француски пантун“ не тежи да иде у правцу књижевне традиције Далеког истока, или то чини веома ретко, као у усамљеном случају Анжеле Ликс, него, сасвим природно, тежи да се приближи сопственој, европској традицији. Ипак, то му не може бити мана.

Укратко, прошавши одређени степен преображаја, „француски пантун“ добија нов квалитет и другачији живот у другачијем књижевном контексту, показујући постојање интеракција различитих културних образаца, где се границе више не препознају. Но, лепота књижевног дела и јесте у томе што као творевина људског духа не признаје границе, већ се, напротив, напаја утицајима са свих меридијана и припада читавом свету. Отуда и овај појам, који је према земљи из које вуче корене назван малајским, у француском књижевном окружењу (а верујемо и у ширем европском контексту), одавно је напустио ту везу и заоденуо се новим рухом, чије нијансе, као и само ткање, имају другачији одсјај и пуноћу. 


\section{ИЗВОРИ И ЦИТИРАНА ЛИТЕРАТУРА}

БодлеР, Шарл. Цвеће зла. Београд: Рад, 1982.

Грдинић, Никола. Формални маниризми. Београд: Народна књига - Алфа, 2000.

Курцијус, Ернст Роберт. Евройска књижевности и лайински среgњи век. Београд:

Српска књижевна задруга, 1996.

ПАриповић КрчмАр, Сања. Сйални йеснички облищи срйской неосимболизма. Београд:

Службени гласник, 2017.

Ревуне́нковА, Еле́на Влади́мировна. Сулалат-Ус-Салатин: Малайская рукопись

Крузенштерна и её культурно-историческое значение. Санкт-Петербу́рг: Петербургское Востоковедение, 2008.

Aquien, Michèle. La versification. Paris: Presses Universitaires de France, 1990.

Banville, Théodore de. Petit traité de poésie française. Paris: A. Le Clère, 1872. <https:// gallica.bnf.fr/ark:/12148/bpt6k50423r.image> 12.10.2019.

CAgliari, Georges de et al. (ur.). L'Anthologie du poème bref. Bordeaux: Les Dossiers d'Aquitaine, 2005.

Chisholm, Hugh (ed.). Pantun. Encyclopaedia Britannica. 20 (11th ed.). Cambridge: Cambridge University Press, 1911, 686.

Collognat-Barès, Annie (ur.). Des troubadours à Apollinaire: Petite anthologie poétique. Paris: Pocket, 2011.

DAILLIE, François-René. La Lune et les étoiles (le pantoum malais). Paris: Les Belles Lettres, 2000.

Des poètes méconnus du Québec: une anthologie: 1800-1950. La Bibliothèque électronique du Québec, volume 72, 2002. <https://beq.ebooksgratuits.com> 12. 10. 2019.

Hugo, Victor. Odes et Ballades. Les Orientales. Paris - Londres - Édimbourg - New York:

Nelson, 1913.

Godin, Gérald. Chansons très nä̈ves. Trois-Rivières: Éditions du Bien public, 1960.

Guiraud, Pierre. La versification. Paris: Presses Universitaires de France, 1978.

JARRETY, Mchel et al. (ur.). Lexique des termes littéraires. Paris: Librairie Générale Française, 2010.

JouEt, Jacques. Échelle et papillons: Le pantoum: Comprenant la réédition intégrale en fac-similé du poème de René Ghil. Paris: Les Belles Lettres, 2005 [1998].

Lamontagne, Blanche. Visions Gaspésiennes. Préface de Adjutor Rivard. Montréal: [s. n.] 1913. <http://numerique.banq.qc.ca/patrimoine/details/52327/2708415> 12.10.2019.

Malay Annals. Translated from the Malay language by John Leyden: with an Introduction by Thomas Stamford Raffles. London: Longman - Hurst - Rees - Orme - Brown, 1821. <http://sebinaol.unior.it/sebina/repository/catalogazione/documenti/Leyden $\% 20$ Malay\%20Annals.pdf $>12.10 .2019$.

Nelligan, Émile. Poésies complètes 1896-1899. Texte établi et annoté par Luc Lacourcière. Montréal - Paris: Fides, 1952. <https://beq.ebooksgratuits.com/pdf/nelligan.pdf > 12. 10. 2019. 
PIA, Pascal (ur.). Album zutique. Paris: Cercle du livre précieux, 1961.

RužÍć, Žarko. Enciklopedijski rečnik versifikacije. Sremski Karlovci - Novi Sad: Izdavačka knjižarnica Zorana Stojanovića, 2008.

SaInt-Jacques, Denis, Maurice Lemire (ur.). La vie littéraire au Québec. T. 5. Sois fidèle à la Laurentie. Sainte-Foy: Les Presses de l'Université Laval, 2005.

SzILÁGYI, Ildikó. Le pantoum au Québec. Molnar, Judit (ur.). Imaginative spaces. Brno: Masaryk University, 2009, 267-278.

Verlaine, Paul. Album zutique. Paris: Éditions du Sandre, 2008.

Verlaine, Paul. Cuvres poétiques complètes. Texte établi et annoté par Y.-G. Le Dantec. Paris: Gallimard, 1989.

VoIsset, Georges. Au fait, vous avez dit pantoun ou pantoum? <https://lettresdemalaisie. com /2012/05/14/au-fait-vous-avez-dit-pantoun-ou-pantoum/> 12. 10. 2019.

VoIsSET, Georges. Histoire du genre pantoun. Paris: L'Harmattan, 1997.

Žıvkovıć, Dragiša (ur.). Rečnik književnih termina. Beograd: Institut za književnost i umetnost - Nolit, 1992.

Diana M. Popović

\title{
MALAY PANTOUN IN FRENCH
}

\section{Summary}

This paper deals with the Malay pantoun, or pantoum, specific poetic form originating from Malaysia and Indonesia, which are geographically and culturally very distant from European and American soil, and therefore from their literatures. We start with the definition of the form itself, discuss its peculiarities, its penetration into the European literary tradition, and focuss on its distribution in French literature, as well as in FrenchCanadian literature. During the research, we noticed that in the French literary circle this specific poetic form was accepted with some adaptations to the Romance cultural and linguistic heritage, while contemporary French-Canadian poetry contains examples of return to malay roots of this poetic form, therefore to its essence.

\author{
Универзитет у Новом Саду \\ Филозофски факултет \\ Одсек за романистику \\ Др Зорана Ђинђића 2, 21000 Нови Сад, Србија \\ diana.popovic@ff.uns.ac.rs
}

